"Public finances, governance control and economic growth: a macroeconomic history approach"

\begin{tabular}{|c|c|}
\hline AUTHORS & $\begin{array}{l}\text { Ola Honningdal Grytten (D https://orcid.org/0000-0003-1416-0980 } \\
\text { R https://publons.com/researcher/1534774/ola-grytten/ }\end{array}$ \\
\hline ARTICLE INFO & $\begin{array}{l}\text { Ola Honningdal Grytten (2019). Public finances, governance control and } \\
\text { economic growth: a macroeconomic history approach. Investment Management } \\
\text { and Financial Innovations, 16(1), 189-202. doi:10.21511/imfi.16(1).2019.15 }\end{array}$ \\
\hline DOI & http://dx.doi.org/10.21511/imfi.16(1).2019.15 \\
\hline RELEASED ON & Monday, 11 March 2019 \\
\hline RECEIVED ON & Thursday, 21 February 2019 \\
\hline ACCEPTED ON & Monday, 04 March 2019 \\
\hline LICENSE & $\begin{array}{l}(\boldsymbol{c c}) \overline{\mathrm{EY}} \\
\text { This work is licensed under a Creative Commons Attribution } 4.0 \text { International } \\
\text { License }\end{array}$ \\
\hline JOURNAL & "Investment Management and Financial Innovations" \\
\hline ISSN PRINT & $1810-4967$ \\
\hline ISSN ONLINE & $1812-9358$ \\
\hline PUBLISHER & LLC "Consulting Publishing Company "Business Perspectives" \\
\hline FOUNDER & LLC "Consulting Publishing Company "Business Perspectives" \\
\hline & $\begin{array}{l}=-\Sigma \\
= \pm:-\end{array}$ \\
\hline NUMBER OF REFERENCES & NUMBER OF FIGURES \\
\hline 46 & 2 \\
\hline
\end{tabular}

(C) The author(s) 2022. This publication is an open access article. 


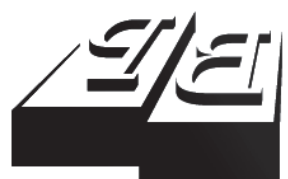

BUSINESS PERSPECTIVES

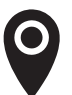

LLC "CPC "Business Perspectives" Hryhorii Skovoroda lane, 10, Sumy, 40022, Ukraine

www.businessperspectives.org

Received on: $21^{\text {st }}$ of February, 2019 Accepted on: $4^{\text {th }}$ of March, 2019

(C) Ola Honningdal Grytten, 2019

Ola Honningdal Grytten, Professor Dr Oecon, Department of Economics, Norwegian School of Economics, Norway.

\section{PUBLIC FINANCES,} GOVERNANCE CONTROL AND ECONOMIC GROWTH: A MACROECONOMIC
HISTORY APPROACH

\section{Abstract}

The size of the public sector is an important tool in public governance. Public sector size may fuel both economic growth and political influence over the economy.

By compiling and processing data from different sources of public accounts the paper aims at mapping the development of key financial indicators for the Norwegian central government sector during the transition period from the mid 19th to the mid 20th century. The data enable us to give measures of the size of the public sector alone and compared to the overall economy.

It is found that the sector started its continuous growth before politicians deliberately started to increase the sector's size of the total economy. The paper also finds that an increase of the public sector often, but not always, reflects political economy regimes. Persistent growth in public finances as a tool for economic policy making did not take place before the introduction of the social-democratic regime in 1935.

The paper also concludes that economic growth started before the growth in the public sector, suggesting that public sector growth might as well be a result of economic growth or vice versa.

\section{Keywords}

\section{JEL Classification}

economic history, financial history, public sector, public finances, public governance

G38, H50, N20, O16, O21, P16

\section{INTRODUCTION}

After the Second World War, the public sector grew rapidly in Western economies. This was deliberate policy by central governments. Today most Western European countries are capitalist economies with large public sectors and substantial public governance.

Focusing on the historical development of one of the Western countries with a larger public sector than the average, we can throw light on the process of transformation from a liberal market economy to a mixed economy, with considerable political governance.

After its independence from Denmark in 1814, Norway arguably was a nation with strong liberalistic influences. As part of widespread liberal attitudes in the nineteenth century, both local and central governments limited themselves to give basic services. Hence, at that time, the size of the public sector was modest. 
On the basis of existing literature, we can trace three major eras on public involvement in the society from the early 1800s until the late 1900s (Seip, 1963; Hodne, 1981b; Hanisch, 1999):

1) the liberal regime 1814-1884 (1905);

2) the social-liberal regime 1884 (1905)-1935;

3) the social-democratic regime 1935 (1945)-1981.

The first phase starts with the Constitution in 1814 and continues to the introduction of parliamentarism in 1884. Though, some historians argue the major shift in regime should be dated to 1905 , when the royal union with Sweden was abandoned. The second phase starts with the introduction of parliamentarism from 1884 and includes the era when social-liberal parties were the major political force. The last phase starts with the first lasting labor party government from 1935 onwards.

The three phases have chiefly served as frameworks for describing and explaining political development (Slagstad, 1987; Sejersted, 2002; Dyrvik, 2013). However, little has been done in order to quantify these issues.

\section{RESEARCH PROBLEM AND BACKGROUND}

On this background, the purpose of the present paper is threefold:

1) firstly, the paper aims at mapping the size of central government during a good hundred-year period from the mid 1800 s to the mid 1900s;

2) secondly, it examines if structural shifts in patterns of public spending and income mirror the three phases of public sector regimes and economic growth;

3) thirdly, it asks if growth of the size of the central government sector as a deliberate action was to gain public control over the economy.

The motivation for starting and ending during the mid 1800s and 1900s is that this span of time makes up a transition period in the public economy. It starts with the liberal state and ends with the introductory years of the new social-democratic regime, i.e. the Nordic model. Before we start with our analysis, we give a historical and macroeconomic background for the development.

\subsection{Public governance}

During the late 1700s, a liberal wave swept over the Western world. After four centuries under
Danish rule, liberal attitudes also gained ground in Norway. In 1779 Wealth of Nations was translated into Danish on Norwegian initiative (Smith, 1776). The new wave was fuelled by the prospect of establishing an independent state in 1814, as Danish over-rule met its conclusion, after campaigning on the French side during the Napoleonic wars.

This gave an opportunity to set up an independent Norwegian government. An elected assembly swiftly constructed a written Constitution and elected a king in May 1814. The constitutional assembly was clearly influenced by liberal ideas adopted from France, the UK and the US.

The move towards independence was not supported by any of the significant powers in Europe, which had agreed upon granting Norway to Sweden as payment for Swedish engagement against France. Thus, Sweden started an armed campaign in July 1814.

After a swift campaign, a revised Constitution was signed on November 4, 1814. It gave more power to the Norwegian parliament and the people than what was given in the initial Constitution from May (Fure, 1989). The Swedish king was to be head of state in a personal union of two independent states. Norway obtained home rule with its own Constitutions, parliament, government, courts, central bank, armed forces and police authority (Rønning, 2005). 


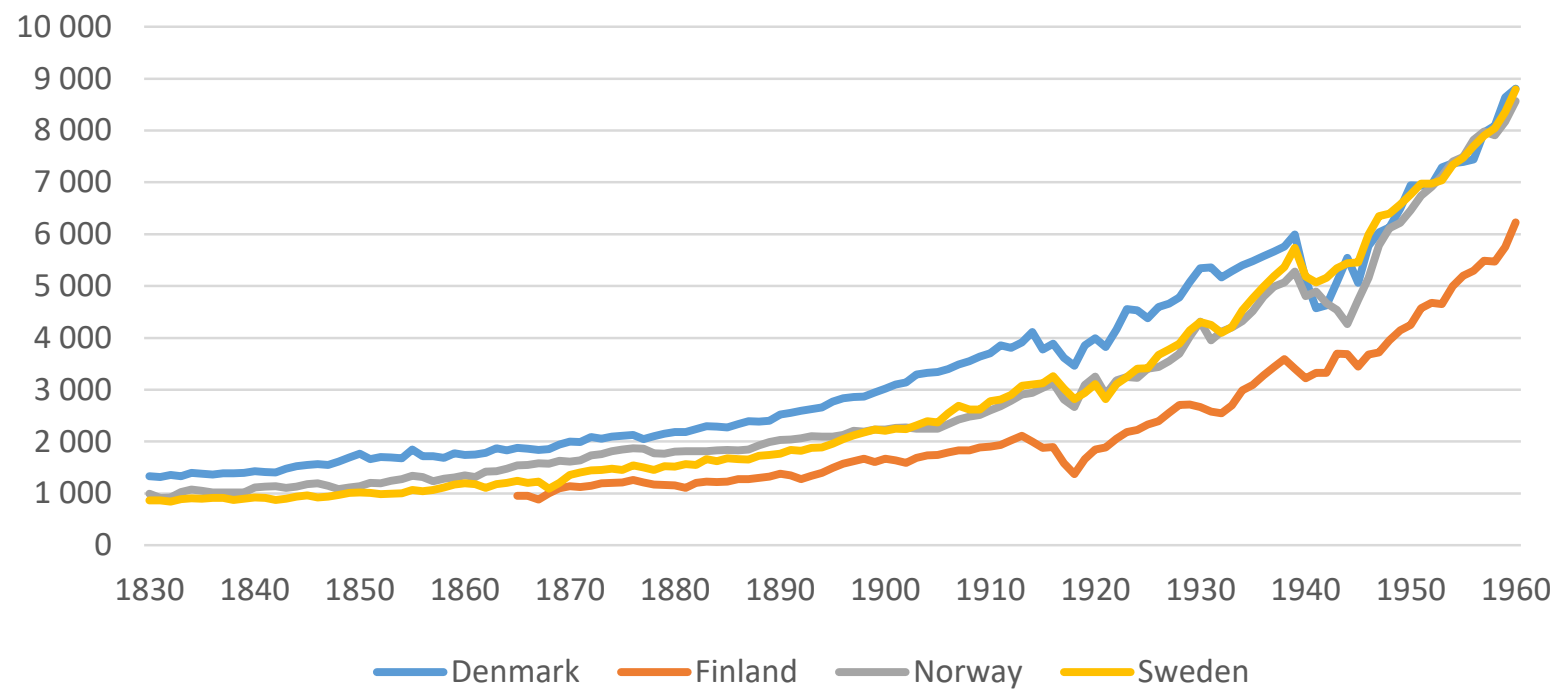

Figure 1. GDP per capita in the Scandinavian countries in 2002, US\$

\subsection{Macroeconomic performance}

Contrary to popular assumptions, Norway was a wealthy country during the 19th century. Gross domestic product per capita levelled that of Western Europe (Bairoch, 1976; Crafts, 1983; Hodne, 1994; Krantz, 2005). Figure 1 shows the relative strength of the Nordic economies. Only Denmark had a stronger economy until the turn of the 19th century.

Figure 2 reports business cycles in the period, calculated as relative output gaps $C_{t}$ between annual real GDP per capita $Y_{t}$ and smoothed GDP per capita $Y_{T}$ :

$$
C_{t}=\log Y_{t}-\log Y_{T}
$$

The polynomial trend is constructed with the help of a Hodrick-Prescott filter (HP-filter). The smoothing parameter, lambda, is set to 2,500 , in line with empirical research on historical business cycles (Grytten, 2012, pp. 3-15).

Economic growth was strong from the early 1840 s to the mid 1870s. After the long depression hit, industrialization was slow and the merchant fleet struggled due to late transformation from sail to steam (Bergh, 1983, pp. 116-122). A domestic property crash and financial crisis fol- lowed in 1899-1905, and industrialization was postponed. From 1905, the breakthrough of hydroelectricity paved the way for rapid industrial expansion.

During the interwar period, the economy saw three deep crises: in the early 1920s, the mid 1920 s and the early 1930s. The first can basically be explained by the international post war depression, the second was due to domestic deflationary monetary policy aimed at bringing the national currency back to its par gold value. The depression of the 1930s hit the small open Norwegian economy through its foreign sector. Unemployment reached a peak level of eleven percent in 1933, just after the business cycle had seen its bottom level (Klovland, 1998, pp. 309-344).

German forces attacked Norway on April 9, 1940. After two months of war, the government capitulated and the country was occupied until May 8, 1945. During this period, the country hosted up to half a million occupants and prisoners of war, accounting up to almost 18 percent of the domestic population. The occupation made public spending rocket. After the war, the public sector was kept large and increasing (Lie, 2012, pp. 99-122). Economic growth reached peak levels, but still lower than in most other Western economies until the 1960s. 


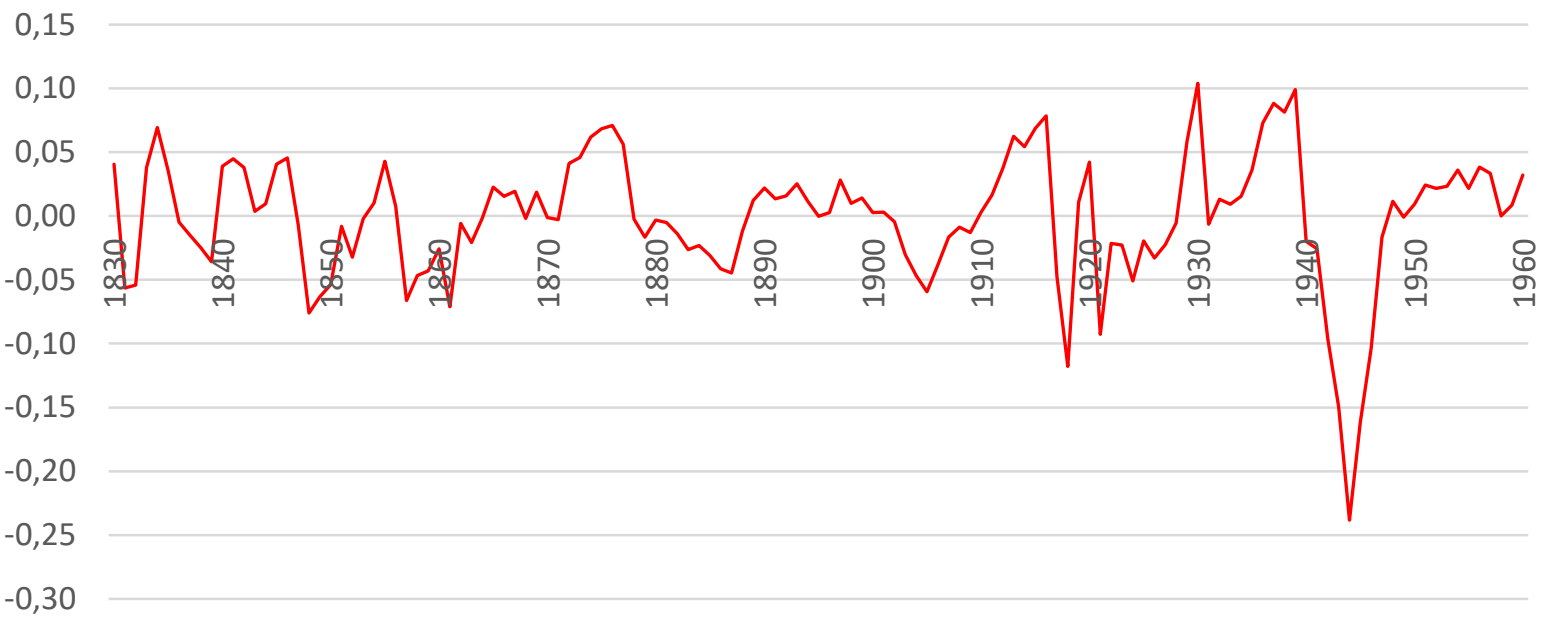

Note: CT is estimated with a HP-filter, with lambda $=2,500$

Figure 2. Norwegian business cycles, measured as output gaps, 1830-1960

\section{THEORETICAL- METHODOLOGICAL FRAMEWORK}

In order to quantify the size of the central government sector, we choose a framework for the establishment of the time series, which is similar to the one used in present and historical national accounts. The sum of central government income is established according to equation (2):

$$
\begin{aligned}
& I N C_{S}=S G S+C I N+T A X_{I}+ \\
& +T A X_{D}+T R A_{L}+T R A_{A},
\end{aligned}
$$

where $I N C_{S}$ - income to central government, $S G S$ - sales of goods and services, $C I N$ - capital income, $T A X_{I}$ - indirect taxes, $T A X_{D}$ - direct taxes, $T R A_{L}$ - transfers from local governments, $T R A_{A}$ - transfers from abroad.

Total central government spending is calculated as expenditure, acording to equation (3):

$$
\begin{aligned}
& E X P_{S}=N P R+N B C+R M B+ \\
& +M V E+O G S+I N T+ \\
& +\left(S U B+T R T_{H}+T R T_{L}+T R T_{A}\right),
\end{aligned}
$$

where $E X P_{S}$ - expenditures by central government, $N P R$ - net purchases of real estate, $N B C$
- new buildings and construction, $R M B$ - repairs and maintenance of buildings and construction, $M V E$ - motor vehicles and other equipment, $O G S$ - other expenditure on goods and services, INT - interest payments, $S U B$ - subsidies, $T R T_{H}$ - transfers to households, $T R T_{L}$ - transfers to local governments, $T R T_{A}$ - transfers to abroad.

In equation (3), $S U B, T R T_{H}, T R T_{L}$, and $T R T_{A}$ together make up total transfers from the central government $T R T_{S}$ :

$$
T R T_{S}=S U B+T R T_{H}+T R T_{L}+T R T_{A} .
$$

Thus, we can write equation (3) on reduced form as:

$$
\begin{aligned}
& E X P_{S}=N P R+N B C+R M B+ \\
& +M V E+O G S+I N T+T R T_{S} .
\end{aligned}
$$

$I N C_{S}$ and $E X P_{S}$ will differ annually. This difference would be denoted as net claim increase $N C I_{S}$, which basically is a residual in our estimates. When $N C I_{S}$ is positive, it means that income is higher than expenditure, and vise versa when it is negative (6):

$$
N C I_{S}=I N C_{S}-E X P_{S} .
$$

Thus, have the following relationship: 


$$
I N C_{S}=E X P_{S}+N C I_{S}
$$

Hence, we also have this relationship that makes us:

$$
\begin{aligned}
& I N C_{S}=N P R+N B C+R M B+ \\
& +M V E+O G S+I N T+S U B+ \\
& +T R T_{H}+T R T_{L}+T R T_{A}+N C I_{S} .
\end{aligned}
$$

By establishing this framework and relationships one is able to construct consistent annual series on the basis of public accounts with data breaks. This also enables one to analyze the development and its structural changes from both the income and the expenditure side.

\section{DATA}

Surprisingly, little has been done to quantify 19th and 20th century public sector regimes. In order to do so, the present paper offers new and persistent estimates of key indicators for the size of the central government. Firstly, annual series of total incomes and spending are put together for the entire period 1840-1960. This is done on the basis of available sources from Statistics Norway and previous research carried out by Bjørsvik (2004) and Hodne (1984).

Hodne has compiled series of the Norwegian central government's annual income and spending for 18251914 (Hodne, 1984, pp. 306-312). Data were taken from governmental and parliamental reports from the time kept by Statistics Norway and the National Archive. Bjørsvik used similar sources to construct value added in the public sector in the frameworks of historical national accounts. She offered refined series of central government income and spending for 1830-1865 (Bjørsvik, 2004, pp. 288-310).

To be able to construct persistent annual series, we have traced the data in the original sources and publications and spliced them when new accounting standards were introduced. From 1860 onwards, we find annual accounts for the central government by the Ministry of Finance (NOS, 1862-1880). These exist both on disaggregated and aggregated levels.
In 1878, the Ministry of Finance published an overview of the central government's finances covering the period 1850-1876 (NOS, 1878). Thereafter, they published similar publications until 1920 (NOS, 1902; NOS, 1922). Persistent series are given both on semi-aggregated and aggregated levels on incomes, spending, assets and debts.

The figures are compiled by the statistical office of the ministry, and include the total accounts of money transactions carried out by the state. According to internal evaluation, the accuracy of the series is "very good", given the standards and definitions at the time.

From 1920 onwards, we compile central government series on key financial figures from Statistics Norway, which have put together relevant series on the basis of accounts from the Ministry of Finance (NOS, 1995). A problem for parts of our series is that the fiscal years cover the period from July 1 in one year to June 30 next year. For these periods, we calculate averages for the two budgets years covering the calendar year, following the equation beneath:

$$
x_{c t}=\frac{x_{b t}+x_{b t+1}}{2},
$$

where $x_{c t}$ is fiscal value $x$ in calendar year $c t$, $x_{b t}$ is fiscal value $x$ in budget year $b t$ and $t+1$ is next year.

Thus, we report continuous and persistent annual series of key financial indicators for the Norwegian central government for 1840-1960 by drawing on previous research by Hodne (1984) and Bjørsvik (2004) until 1849, the Ministry of Finance until 1920, and thereafter Statistics Norway until 1960. Thus, we end up with fairly valid and reliable series of the size of the central government administration for the time in question.

\subsection{Size of central government sector}

Figure 3 reports the annual calculated size of the central government sector in percent of total GDP for Norway for 1840-1960. As can be seen from the graph, there is a long-term development upwards in the size of the central government sector during this period from around five percent in the mid 1800 s to between 15 and 20 percent in the mid 1900s. 

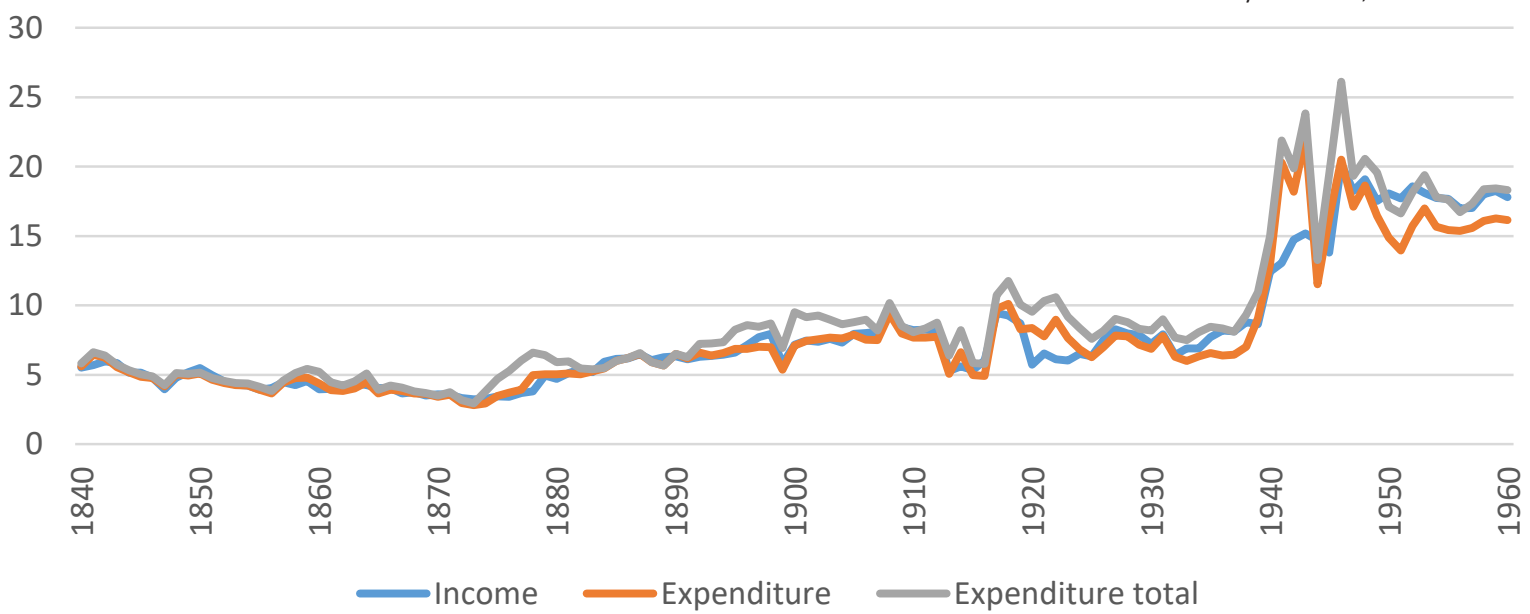

Figure 3. Central government sector income and spending in percent of GDP, 1840-1960

Looking at the composition of spending, we find that defence had a long-term decline as share of the total, when basic investments increased rapidly. Administration and debt service were quite stable as share of total central government spending in the long run.

\subsection{Structural breaks and policy regimes}

After having quantified the size of the public sector, we ask if this development mirrors the three abovementioned policy regimes. In order to map structural breaks, here defined as significant change of trend or pattern of public expenditure as share of GDP, we again use the HP-filter. We use the standard smoothing parameter of 100 for the annual series presented here.
As can be seen from the graph, both income and spending as share of GDP fell until the early 1870 s from around six to close to three percent. Then, we find a structural shift, with a significant trend upwards until the aftermath of the Second World War. We also find a consolidation period until the early 1930s, and another structural shift with moderate increase until the outbreak of the war in 1939. Thereafter, we find a last shift followed by a more stabilizing pattern in our figures after the war.

In Table 1, we compare the structural breaks in the series with commonly claimed phases of policy regimes according to the literature. As can be seen in the table, quantification suggests that the peaks and bottoms in the series do not coincide with the common periodization of policy regimes.

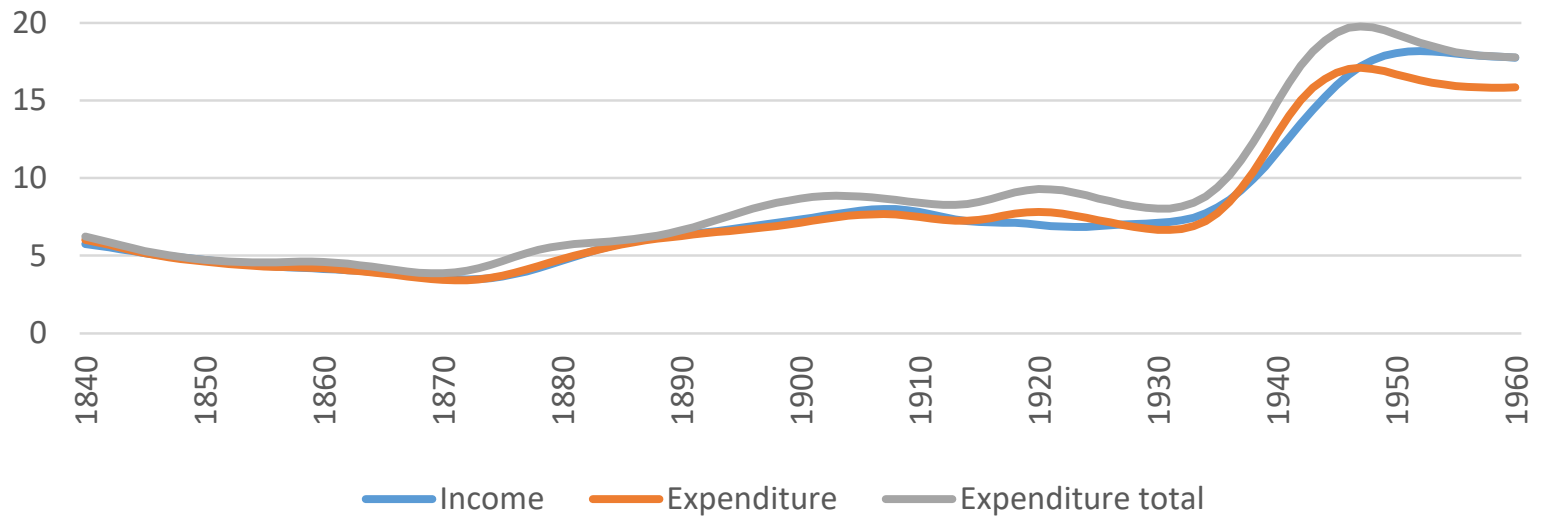

Note: Lambda $=100$.

Figure 4. HP-trend of central government sector income and spending in percent of GDP, 1840-1960 
A significant increase in public spending and income started around 1872, and not when parliamentarism was introduced in 1884 . This is in line with what some historians have identified as the start of the modernization process (Myhre, 2012).

Table 1. Central government policy regimes according to literature and according to quantification of sector

\begin{tabular}{|c|c|c|}
\hline & Break between & Break between \\
\hline Parameters & $\begin{array}{l}\text { Liberal and } \\
\text { social-liberal } \\
\text { regime }\end{array}$ & $\begin{array}{c}\text { Social-liberal and } \\
\text { social-democratic } \\
\text { regime }\end{array}$ \\
\hline Literature dating & 1884 (1905) & 1935 (1945) \\
\hline $\begin{array}{l}\text { Expenditure } \\
\text { dating }\end{array}$ & - & - \\
\hline Current figures & 1873 & 1933 \\
\hline HP-trend & 1871 & 1931 \\
\hline Income dating & - & - \\
\hline Current figures & 1873 & 1932 \\
\hline HP-trend & 1871 & 1931 \\
\hline
\end{tabular}

We also find that a new wave of a fiscally more active state was introduced from 1931, i.e. four years before the labor party came into office. Thus, the size of the central government sector started its increase before the common dating of the political paradigm shifts. Hence, was the increase in the central government finances a tool for gaining more control over the economy?

\subsubsection{Patterns of spending}

The sources allow us to disaggregate spending as reported in Figure 5. Defence was rapidly declining as share of total spending during most of the period under investigation, when basic investments, chiefly in physical and educational infrastructure, increased substantially.

In Figure 6, decomposed as percentages of total spending are reported as HP-trends with the annual smoothing parameter set at 100 . The increase in basic investment spending as share of total spending came previous to 1884 and not after. In fact, basic investments did not regain its 1880 level before the early 1920s. It is also interesting to see that basic investments had their take-off as debt payments decreased rapidly (Hodne, 1984).

Another trend is the almost symmetric increase in basic investments and decrease in defence spending in the 1920s and early 1930s. The first is the result of central government investment policy during the depression, with many bankrupt local governments. The latter is the consequence of a stressed financial situation and a strong pacifist political movement (Nordvik, 1979, pp. 223-238).

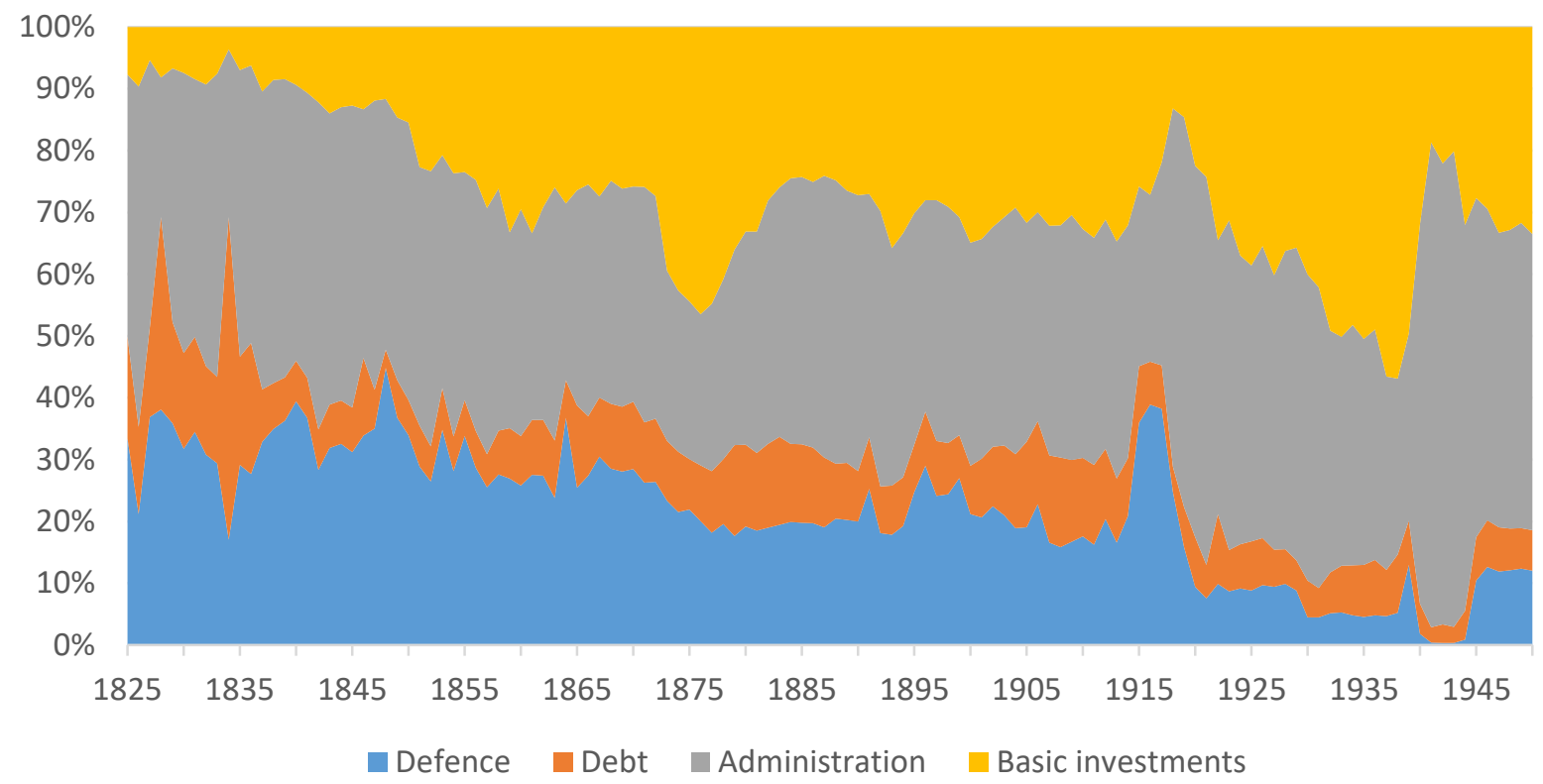

Figure 5. Central government spending by composition as share of total in percent, 1825-1950 


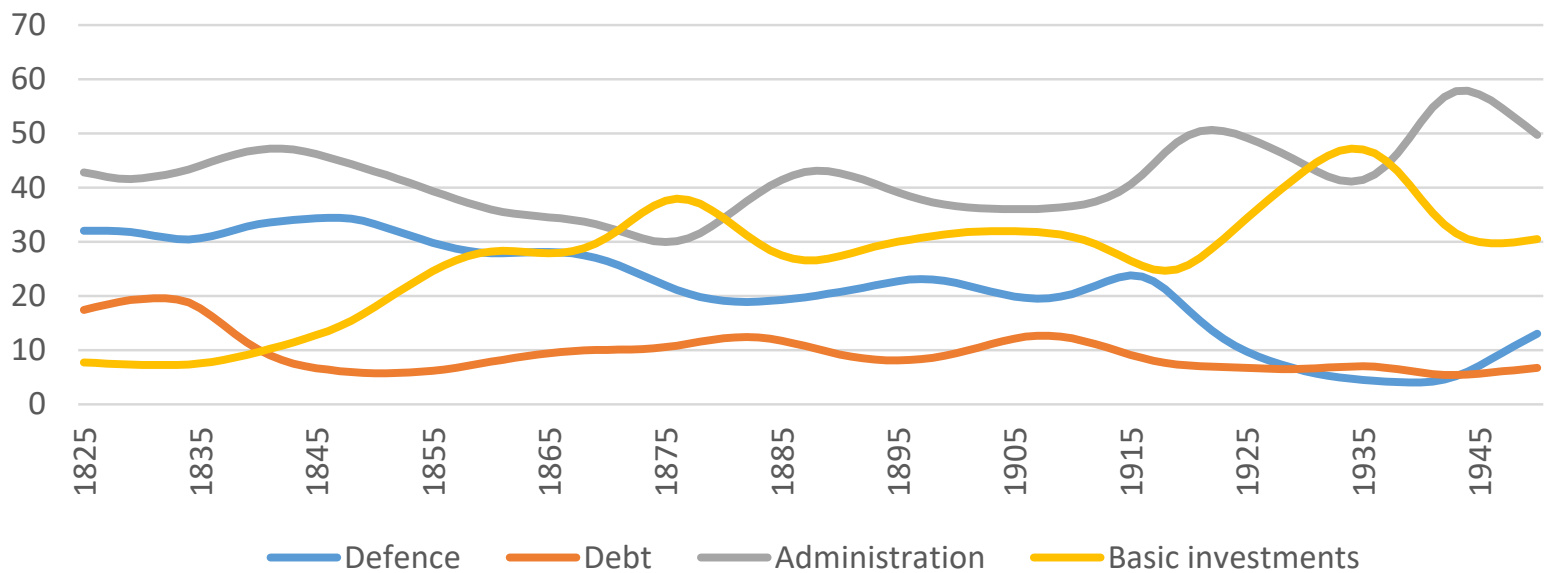

Note: HP-trends, lambda $=100$.

Figure 6. Central government spending by composition as share of total in percent, 1825-1950

The fiscal balance of the central government provides us with important information related to when huge deficits occurred. Were these deliberate?

Figure 7 reveals deficits in the state finances basically occurred during turbulent years, e.g. the Crimean financial crises in the late 1850 s, the Kristiania crisis 1899-1905, and the two great wars, including the post First World War depression. This indicates that the deficits were not planned, but came as market reactions on macro economic shocks. Thus, they were not deliberate actions in order to increase the central government sector as part of public governance.
An exception from the macro economic shock patterns seems to be during the 1870s. During this decade, a large public investment program in infrastructure, basically railways, ports and roads explain the huge deficit (Hodne, 1984).

\subsection{Liberal regime}

The Norwegian political paradigm until the late nineteenth century has seen an era of the liberal state. Individual rights were emphasized, and the central government defended these. Constitutional rights were given to citizens, but with limitations. The Lutheran state church was still the public religion, and free churches and Jews were not allowed

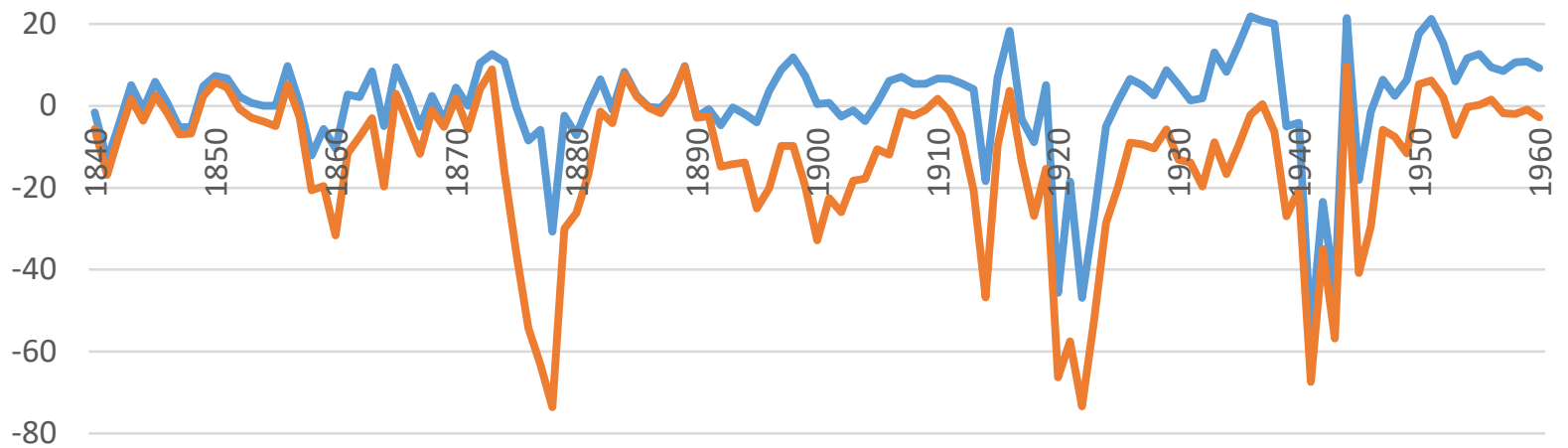
Surplus $\quad$ Surplus after capital expences

Figure 7. Fiscal balance, central government, percent of income, $1840-1960$ 
until 1842 and 1851, respectively (Supphellen, 2012, pp. 100-121).

There were several reasons why Norway maintained a liberal order during the 1800s. Firstly, the constitution of 1814 was liberal for its time. This attitude was reflected in contemporary views on governmental involvement. Secondly, one saw defence of national sovereignty as a most important task during the entire 19th century. It was done by building national institutions and emphasizing liberal rights. Thirdly, the inhabitants had learned to appreciate distance to the central government during the union with Denmark. Now they wanted to keep the distance to Sweden in order to be their own rulers. Fourthly, it was beneficial for a small open economy to welcome liberalism with free trade (Hodne, 1981a, pp. 23-34). Along with the international liberal wave, these factors influenced the public governance during the personal union with Sweden until 1905.

From the 1850s and onwards, liberal attitudes were dominant in most respects of governance. By 1842, the toll tariffs were reduced significantly. Thereafter, several new laws were made in order to liberalize the capital, labor and product markets. The most important of these are listed in Table 2.

Table 2. Liberal laws concerning the economy introduced in the 19th century

\begin{tabular}{|c|c|c|c|}
\hline Law on & Year & Law on & Year \\
\hline $\begin{array}{l}\text { Swedish- } \\
\text { Norwegian trade }\end{array}$ & 1827 & Mining & 1842 \\
\hline Crafts & 1839 & Herring fisheries & 1851 \\
\hline Tariffs & 1842 & $\begin{array}{l}\text { Abolishment of saw } \\
\text { mill privileges }\end{array}$ & 1854 \\
\hline Domestic trade & 1842 & $\begin{array}{l}\text { Cod fisheries } \\
\text { (Lofotloven) }\end{array}$ & 1857 \\
\hline $\begin{array}{l}\text { Free interest } \\
\text { rates }\end{array}$ & 1842 & $\begin{array}{c}\text { Swedish-Norwegian } \\
\text { trade }\end{array}$ & 1874 \\
\hline
\end{tabular}

During this period, public servants represented the central government locally. An important feature was to see too that the liberal system was maintained. Farmers and Haugeans, followers of the religious, social and economic entrepreneur of his time, Hans Nielsen Hauge, 1771-1824, often challenged them (Minde, 2019).

Most Norwegian farmers were independent. They fought for liberty and limitation of public spending and involvement (Pettersen, 1982, pp. 4-21).
The Haugeans established networks of entrepreneurs within industry, labor welfare, education and social innovations. They were spokesmen for economic and political liberalism (Grytten, 2013, pp. 31-44). The two groups together made up a dominant force in parliament during the 19th century (Skullerud, 1971).

\subsubsection{Institutions}

For a new independent national state, from 1814 it was imperative to build own institutions. These were primarily meant to serve the people. They should offer the best possible infrastructure to the lowest possible cost. The state was supposed to maintain good and stable frameworks for such a development.

The local governments were to finance the state church, schooling and poverty relief. However, most services, which are presently considered public, were offered by the private sector. Families, employers and the church had the major responsibility for welfare and social support. Thus, many companies introduced unemployment benefits, retirement pensions and other welfare arrangements long before the state cautiously started with such measures in the late 1930s.

The Norwegian central bank was founded as a limited private company in 1816 . The speciedaler was introduced as national currency. The bank's headquarters were first located in Trondheim, far from the hands of the central government. However, money was to be printed in the capital, Christiania. Due to fiscal problems and lack of confidence, the speciedaler did not reach its par value until 1842 (Eitrheim, 2016).

The silver standard was exchanged for the international gold standard on January 1, 1874. Thereafter, the speciedaler gave way to the krone, as Norway entered the Scandinavian Currency Union three years later. The rational behind both the silver and the gold standard was to give money fixed values without interference from politicians. By maintaining fixed currency rates, it would also be easier to attract foreign capital and trade. In addition, the central bank was responsible for maintaining an efficient credit market and bank industry, and was a significant lender, both to banks and to the business community (Klovland, 2013). 
Direct taxes to the state were abolished for rural areas in 1836. The decision lasted until 1892. Within this period, export tariffs were totally abolished and import tariffs reduced to a minimum. In consequence, the central government income was at a very low level. And there was limited room for financial manoeuvring (Gerdrup, 1998, pp. 8-17).

As late as 1880, the central administration had a staff of only 550 . With a population of $1.915 \mathrm{mil}-$ lion, that meant close to 3,500 inhabitants per central administration employee. They were basically lawyers, whose main task was to secure the rule of law according to the liberal era. The bureaucracy should in principle not take initiatives, but to see that decisions made by the popular vote through elected representatives were carried out.

\subsubsection{Reorientation}

The end of the deflationary policy aiming at reaching par value of the speciedaler came to its conclusion in 1842. From then on, more emphasis was put on building physical and educational infrastructure. In consequence, technical expertise was recruited to the central administration. These were, until the establishment of the Norwegian School of Technology in 1910, educated abroad. The entrance of the engineers marked a new phase in the tasks carried out by the state. More emphasis was put on building practical frameworks to fuel the economy.

Infrastructure became more important. Educational and health-related investments, construction of roads, post and public steamship services took off already from the 1840 s. Thereafter, railroads, ports and the telegraph, followed from the 1850s (Hodne, 1984, pp. 306-312).

Since the population growth was close to one percent per annum, it also became important to take measures for the agricultural sector to secure domestic food supplies. Hence, the state welcomed private schools for agricultural education. This was followed up with the establishment of the Norwegian School of Agriculture in 1854. Investments in infrastructure peaked in 1877, when railway construction stood at its highest. From then on, its relative share was reduced.
To sum up, during the liberal era, the size of the central government sector fell relative to the economy until the early 1870 s. From then on, the significant growth in basic investments, which started as early as the 1840 s, made the sector to grow faster than the overall economy. Parliament definitely saw a special responsibility for building infrastructure long before the social-liberal era came to being around 1884. However, it was no deliberate action in order to gain more control over the economy.

\subsection{Social-liberal regime}

Democracy was extended in line with the political development. In 1814 , only 6.5 percent of the population was granted the right to vote in parliamentary elections. In 1884, parliamentarism was introduced after a long-lasting conflict with the king. From then on, the national government was basically responsible to the national assembly and needed its majority support in order to govern. Voting was extended to all men who paid a certain amount of tax. From 1898 all adult men were included. Finally, women gained their right to vote in central elections from 1913 (Sørensen, 1984).

As part of the new system, politics changed. Since in reality the national assembly, and not the Swedish king, now appointed the national government, the importance of limiting his influence had ceased. Hence, there was a room for more active central government administration. The modernization of central administrations in Europe also implied strengthening of the bureaucracy.

The social liberal party, Venstre, gained significant political power as the major force in the centre of domestic policy. This power was used to introduce new laws and more direction in budget policy. The state became more active within welfare, education and health services (Grebstad, 1984). At the same time, liberal principles on individual freedom, local government and market liberalism were maintained. We find a deliberate political effort put into a more active public sector aimed at benefiting both the individual and the society at large.

Economic growth and modernization also demanded a more active state in order to motivate industrialization, protect natural resources and 
increase human resources through schooling and education. The increase of the standard of living came along with an increasing attention on health services (Larsen, 1986). When Norway finally abandoned the personal union with Sweden in 1905 , more spending had to be used on diplomacy and foreign services.

After relative stagnation and deflation from the mid 1870s until 1887, a new wave of industrialization gained momentum in the 1890s. This was connected to hydroelectricity. There was a huge need to construct power stations and related industry. Both local and central authorities were engaged in capital imports from the UK, Germany, Denmark and Sweden. The creation of Norsk Hydro in 1905, with central government support, was a benchmark, as it became a dominant international producer of fertilizers, and ferroalloys (Venneslan, 2009, pp. 124-155).

From the 1890s new protectionism swept over Europe. Influential alliances from the politi$\mathrm{cal}$ and the business community questioned the huge influx of foreign capital, as 75 percent of the regulated Norwegian waterfalls and 80 percent of the chemical industry belonged to foreigners (Stonehill, 1965, pp. 44-47).

After a heated debate, prime minister Gunnar Knutsen and the social-liberal party gained majority for introducing protective concession laws in 1906-1917. Local and central governments could restrict foreign ownership of domestic natural resources (Thue, 1992). As result of these actions, the public sector, and in particular local governments, became grand investors and owners of power plants. Thus, the public sector grew in hunt for national control.

\subsubsection{Crisis response}

As a tool of counter-cyclical policy both key industries were subsidized during the war in 1914-1918. In consequence, the central government administration reached a financial peak level around 1920.

Deflationary policy aimed at restoring par value of the krone after the war gave additional deflationary pressure during the post-war depression in the early 1920s. The policy was in line with liberal ideals at the time and included a substantial tightening of credit and money volumes. Product demand fell and war inflation was turned into deflation. The central bank increased nominal interest rates, and real wages before tax almost reached astonishing 40 percent. Additionally, currency depreciation was turned to appreciation. Debt became increasingly more expensive and product demand fell (Hanisch, 1979, pp. 239-268).

GDP per capita contracted by eleven percent in 1921 alone. Unemployment rocketed to around eight percent in the years to come, and more than a hundred commercial banks went bankrupt (Nordvik, 1995). Due to highly indebted municipalities, the national government took action to stimulate the economy. Banks were bailed out, and the central administration had to take over significant parts of the infrastructure responsibilities. At the same time, the central administration's fiscal power was limited, despite increasing spending on infrastructure (Eitrheim, 2016).

When the Great Depression hit the world economy from 1929, the central government again took action. The public sector saw a new wave of relative increase from the early 1930s, and important markets were regulated. Parliament monopolized first hand sales of fish by law in 1929-1938. As for agriculture, producers of crops were subsidized by the state from 1927 and guaranteed a minimum price one year later. In 1930, the parliament decided on regulating the markets for dairy products, eggs and bacon. From 1931, all milk producers had to pay a fee to a regulatory body in order to level the price of milk. This was followed up by a law demanding butter to be mixed into margarine to solve the problem of access production of milk (Hovland, 1979, pp. 305-325).

\subsubsection{Planning for larger public sector}

The central government sector again started to increase as share of GDP. This can partly be explained by the huge contraction in industrial output, and partly by active policy, making the public sector grow relatively to the private. Political and economic crises during 1914-1945 paved the way for greater state intervention. Thus, one saw the birth of a social-democratic regime. 
The public sector intentionally grew stronger under the social-democratic rule in the 1930s. Budget discipline was nevertheless maintained. Thus, fiscal policy should not be considered typical Keynesian. In September 1931, the gold standard regime was in practice abandoned. This implied a transformation from deflationary to inflationary monetary policy. The krone depreciated against other currencies and both domestic and foreign demand revived (Venneslan, 2010). Despite the recovery, unemployment stayed persistently high until the 1941. Nevertheless, the foundations for a more active state, under a social-democratic rule, were laid.

\subsubsection{Social-democratic regime}

A crisis agreement between the Labor Party and the Farmers Party established the new era in 1935. Norway's second labor government ever which came to office until 1965, only interrupted by a one-month's centre-right government in 1963.

Until 1940, the country still had a small public sector, counting for eleven percent of GDP in the late 1930s. During the German occupation, from April 1940 till May 1945, it grew rapidly. When the war was over, the Labor Party took the opportunity to increase the size of the sector. Their policy also implied increased centralization. Clear strategic goals were set. Detailed regula- tions played an important role, set out by the parliament, the central government and the central administration.

The era marked the entrance of the economists into the central administration. They were educated in and believed in economic planning. Markets became regulated in detail. Until 1952, it was basically to avoid strong inflation, lack of hard currency and economic crisis. Thereafter, the planning model was basically used to outlevel the business cycles, reduce income differences and market failures, secure tax incomes and social security programs, and monitor the economy into a planned track. The Scandinavian neighbors, Denmark, Finland and Sweden, followed a similar pattern, called the Nordic model (Søilen 2002).

The idea of a free market was out, planning was in. A new homogenous society became a consensus society under the wings of the state. The public sector grabbed the welfare responsibility from families, local communites, employers and churches. The welfare state was created.

Thus, we see that the increase of the central government sector was a continuation of a process that started in the early 1930s. Under social-democratic rule from 1935, the development was part of a political agenda. Growth of the public sector was part of a plan to gain control over the economy.

\section{CONCLUSION}

Most Western European economies went through three stages of public governance regimes between the mid 1800s and the mid 1900s: a liberal regime, a social-liberal regime and a social-democratic regime. This process was very clear in the Nordic countries. Here we use one of them, Norway, as a case. By compiling data from a wide range of sources, the paper seeks to answer three questions concerning public finance and its link to economic growth and public governance:

1) What was the size of public spending?

2) Do structural shifts in patterns of public spending and income mirror the three phases of public sector regimes and economic growth?

3) Was growth of the size of the central government sector a deliberate action to gain public control over the economy?

During the liberal era, the central government sector decreased relative to the overall economy. Thereafter, the state sector increased rapidly due to investments in infrastructure. The relative size of the sector continued to increase under the social-liberal era before its rapid growth under social-democratic rule. 
We find that the growth of the central government does neither necessarily coincide with economic growth nor the introduction of political regimes. Persistent economic growth started before the growth of the public sector, when fiscal transition started in front of political transitions.

Growth in central government finances during the last part of the liberal era was basically to fuel economic growth and development. During the social-liberal era, the sector seemed to grow faster than the economy due to ambitions of more active and responsible state. In the social-democratic era, growth in the public sector aimed at gaining control over the economy.

\section{REFERENCES}

1. Bairoch, P. (1976). Europe’s Gross National Product 1800-1975. Journal of European Economic History, 5(2), 273-340. Retrieved from https://www.econbiz.de/ Record/europe-s-gross-nationalproduct-1800-1975-bairochpaul/10009926116

2. Bergh, T., Hanisch, T. J., Lange, E., \& Pharo, H. (1983). Norge fra u-land til i-land: vekst og utviklingslnjer 1830-1980. Oslo: Gyldendal.

3. Bjørsvik, E. (2004). Public Services in Norway 1830-1865 within the framework of historical national accounts. Bergen: NHH.

4. Crafts, N. F. R. (1983). Gross National Product in Europe 1870-1910: some new estimates. Explorations in Economic History, 20(4), 387-401. https://doi. org/10.1016/0014-4983(83)90026-8.

5. Eitrheim, Ø., Klovland, J. T., \& Øksendal, L. F. (2016). A Monetary History of Norway, 1816-2016. Cambridge Mass: Cambridge University Press.

6. Feinstein, C. H. (Ed.) (1995). Banking, Currency and Finance in Europe between the Wars. London: Clarendin.

7. Fure, E. (1989). Eidsvoll 1814. Oslo: Dreyer.

8. Gerdrup, K. (1989). Skattesystem og skattestatistikk i historisk perspektiv. Rapporter, 98(6), 8-17. Retrieved from https:// www.ssb.no/a/histstat/rapp/ rapp_199806.pdf

9. Grebstad, O., \& Nærbøvik, J. (Eds.) (1984). Venstres hundre år. Oslo: Gyldendal.
10. Grytten, O. H., \& Hunnes, A. (2012). A long term view on the short term co-movement of output and prices in a small open economy. International Journal of Economics and Finance, 4(2), 3-15. http://dx.doi.org/10.5539/ ijef.v4n2p3

11. Grytten, O. H. (2013). The Protestant Ethic and the Spirit of Capitalism: Entrepreneurship of the Norwegian Puritan Leader Hans Nielsen Hauge. Review of European Studies, 5(1), 31-44. http://dx.doi.org/10.5539/res. v5n1p31

12. Hanisch, T. J. (1979). Om virkninger av paripolitikken. Historisk tidsskrift, 58(3), 239-268.

13. Hanisch, T. J., Søilen, E., \& Ecklund, G. (1999). Norsk økonomisk politikk i det 20 århundre. Kristiansand: Høyskoleforlaget.

14. Dyrvik, S., Grønlie, T., Helle, K., \& Hovland, E. (2013). Grunntrekk i norsk historie: fra vikingtid til våre dager. Oslo: Universitetsforlaget.

15. Hodne, F. (1981a). An Economic History of Norway, 1815-1970. Trondheim: Tapir.

16. Hodne, F. (1981b). Norges økonomisk historie 1815-1870. Oslo: Universitetsforlaget.

17. Hodne, F. (1984). Stortingssalen som markedsplass: Statens grunnlagsinvesteringer 1840-1914. Oslo: Universitetsforlaget.

18. Hovland, E. (1979). Smør og margarin blir et fett. Historisk tidsskrift, 58(1), 305-325.

19. Klovland, J. T. (1998). Monetary policy and business cycles in the interwar years: The Scandinavian experience. European Review of Economic History, 2(3), 309-344. Retrieved from https://www.jstor. org $/$ stable $/ 41377836$ ?seq=1\#page scan tab_contents

20. Klovland, J. T., \& Øksendal, L. F. (2013). The decentralised central bank: regional bank rate autonomy and capital market integration in Norway, 1850-1892. European Review of Economic History, 21(3), 259-279. http://dx.doi.org/10.2139/ ssrn. 2233948

21. Krantz, O., \& Nilsson, C. A. (1974) Relative income levels in the Scandinavian countries. Economy and History, 17(1), 52-69.

22. Larsen, Ø., Berg, O., \& Hodne, F. (1986). Legene og samfunnet. Oslo: DnL.

23. Lie, E. (2012). Norsk økonomisk politikk etter 1905. Oslo: Universitetsfolaget.

24. Minde, K. B. (2019). Puritan liberal parliamentary voting (Unpublished manuscript). Stord: HVL.

25. Myhre, J. E. (2012). Norsk historie 1814-1905. Å byggje ein stat og skape ein nasjon. Oslo: Universitetsforlaget.

26. Nordvik, H. W. (1979). Finanspolitikken og den offentlige sektors rolle i norsk økonomi i mellomkrigstiden. Historisk tidsskrift, 58(1), 223-238. Retrieved from https://aggb-katalog.de/vufind/Record/ifz.183916

27. Nordvik, H. W. (1995). Norwegian Banking in the Inter-War Period: A Scandinavian Perspective. In C. H. Feinstein (Ed.), Banking, Currency and Finance in Europe between the Wars (pp. 434-457). London: Clarendin. 
28. Norges Oficielle Statistik D. No. 1 (1862-1880). Oversigt over Kongeriget Norges Indtoegter og Udgifter, 1860-1878. Christiania: Finants-Departmentet.

29. Norges Oficielle Statistik D. No. 1b (1878). Kongeriget Norges Finantser i Aarene 1850-1876. Kristiania: Finants-Departementet.

30. Norges Officielle Statistik No. 35 (1902). Statistik over Den Norske Statskasses Finantser I Budgetaarene 1juli 1885 til 30 juni 1890. Kristiania: Den Kongelige Norske regjerings Finants-og Told-Department.

31. Norges Offisielle Statistikk VII. 59 (1922). Den norske statskasses finanser. Kristiania: Finans og Tolldepartementet.

32. Norges Offisielle Statistikk C 188 (1995). Historical Statistics 1994. Oslo: Statistics Norway.

33. Pettersen, P. B. (1982). Liberaleren fra Lista: Et nytt syn på Søren Jaabæk. Ideer om frihet, 2(3), 4-21.

34. Rønning, B. R. (2005). Stortinget og unionen med Sverige: dokumenter fra Stortingets arkiver, 1814-1905. Oslo: Stortinget.

35. Seip, J. A. (1963) Fra embedsmannsstat til ettpartistat og andre essays. Oslo: Universitetsforlaget.

36. Sejersted, F. (2002). Demokratisk kapitalisme. Oslo: Pax.

37. Skullerud, A. (1971). Bondeopposisjonen og religionsfriheten i 1840-årene. Oslo: Universitetsforlaget.

38. Slagstad, R. (1987). Rett og politikk: Et liberalt tema med variasjoner. Oslo: Universitetsforlaget.

39. Smith, A (1776). An Inquiry into the Nature and cases of the Wealth of Nations. Glasgow/Edinbourgh.

40. Stonehill, A. (1965). Foreign ownership in Norwegian enterprises. Samfunnsøkonomiske studier, 14, 44-47.

41. Supphellen, S. (2012). Konventikkelplakatens historie 1741-1842. Trondheim: Tapir.
42. Søilen, E. (2002). Hvorfor gikk det galt? Statens rolle i utviklingen av norsk næeringsliv etter 1945. Oslo: Gyldendal.

43. Sørensen, Ø. (1984). 1880-årene: Ti år som rystet Norge. Oslo: Universitetsforlaget.

44. Thue, L. (1992). The state and the dual structure of the power supply industry in Norway 1890-1940. In M. Trédé (Ed.), Ėlectricité et électricification dans le monde 1880-1980. Paris.

45. Venneslan, C. (2009). Electrification and Industrialisation: An assessment of the industrial breakthrough in Norway. Scandinavian Economic History Review, 57(2), 124-155. https://doi. org/10.1080/03585520902799638

46. Venneslan, C. (2010). Norway's recovery from the Great Depression - an act of balancing? Scandinavian Economic History Review, 58(2), 119-138. https://doi.org/10.1080/035 85522.2010.482287 